\title{
MINING
}

\section{MODELING OF INTERACTION OF INCLINED SURFACES OF A HYDRAULIC CLASSIFIER WITH A FLOW OF SOLID PARTICLES}

Purpose. Development of a mathematical model of the interaction process of a solid particle driven by a highspeed head of a carrier medium with an inclined surface of a hydraulic classifier.

Methodology. The theory of granular material single particles transfer by a two-phase heterogeneous flow in the boundary region between the inclined surface of the classification apparatus and the aqueous medium is applied. The interaction of a solid particle with an inclined surface under the influence of the speed head of an expanding carrier stream, as well as gravity, Archimedes, friction, and environmental resistance is considered.

Findings. A mathematical simulation of the interaction of solid particles with an inclined surface is performed under the influence of the speed head of the carrier medium. Three characteristic modes of particle motion are considered: the surface is horizontal, inclined downward, inclined upward. As a result of the development of the process model of interaction between the flowing part of the new technical level classifier, formed by dissimilar surfaces, with solid particles washed by a passing flow of the carrier medium, regularities in the influence of the slope angle of the classifier flowing part surface on the parameters of the solid particle equilibrium state are formulated. Analytical dependencies are obtained to determine the characteristic velocities of the carrier medium flow sufficient for the equilibrium of a solid particle. It has been established that the impact on a solid particle located on the classifier inclined surface with a carrier flow whose speed is proportional to the surface slope angle, the coefficient of sliding friction, the characteristic diameter, will allow it to keep its equilibrium.

Originality. Analytical dependencies are obtained to determine the characteristic velocities of the carrier medium motion required for the equilibrium state of the particles deposited on the inclined surface of the classification apparatus.

Practical value. Analytical dependencies are obtained to determine the medium flow velocity which carries solid particles from the inclination angle of the classification apparatus flowing part wall. The established dependencies make it possible to justify the rational angles of the surfaces slope that form the flowing part of the horizontal classifiers and other classification apparatus used for the gravitational processing of granular materials.

Keywords: hydraulic classifier, gravitational processing, inclined surface, grain material

Introduction. The processes of gravitational processing of granular materials are among the most demanded in the industry for the production of quality non-metallic building materials, the enrichment of non-ferrous metal ores, in the preparatory processes of enrichment production $[1,2]$. For the purification of granular material extracted or processed hydromechanically by open or underwater mining, it is rational to use horizontal hydraulic classifiers of traditional designs [3], as well as installations of a new technical level (Fig. 1). This concept of a horizontal hydraulic classifier can also be used for clarification of mine waters [4, 5], which requires the completion of its hull design taking into account specific installation conditions [6, 7].

Classifier hydraulic horizontal consists of a flowing part, divided into sections: separation 1, classification 2, flow 3 and a hopper for the accumulation of granular material 4 (Fig. 1).

(C) Bondarenko A. O., 2018
Analysis of recent the research and publications. Description of the pulp flow run, as well as the process of solid particles gravitational classification in the horizontal flow of pulp within the differently inclined surfaces of the horizontal hydraulic classifier was performed earlier. The mathematical model of the horizontal motion of a particle carrying a solid particle is developed using the Euler equation for an ideal fluid in Cartesian coordinates [8]. The basis for the simulation included mathematical models developed to describe the interaction of solid particles and the flow of pulp in the underwater face of a suction dredge $[9,10]$. Adaptation of the mathematical model with respect to pulp motion within the flow part of the hydraulic classifier is given in [11, 12].

However, the process of interaction of inclined surfaces of gravitational devices with a directed flux of precipitated granular material remained unexplored.

Unsolved aspects of the problem. The common feature of gravity processes of mineral processing is the 


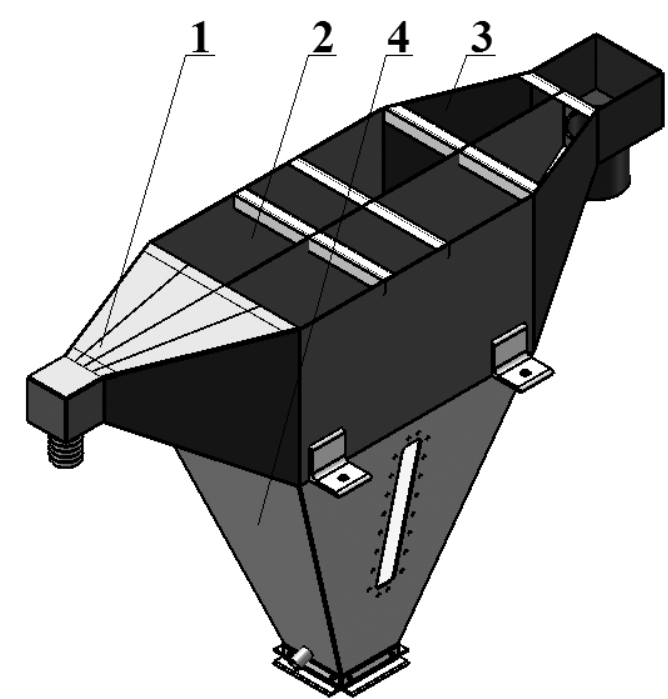

Fig. 1. Model of the horizontal classifier [12]

movement of granular materials along inclined surfaces that form the flowing part of the classifier. The high-speed head of a bearing medium can have a decisive influence on the possibility of the movement of granular material along an inclined surface. Accounting for the effect of high-speed head will result in rationalization of the transportation process, development of methods for justification of classifier design parameters and, as a result, reduction in the metal intensity of equipment. Thus, the development of a model for the interaction of solid particles with inclined surfaces driven by a high-speed head of a carrier medium is an important scientific and technical task, the solution of which will allow reducing the prime cost of the gravitational classification of mineral raw materials.

Objectives of the article. The purpose of this work is to develop a mathematical model for the interaction of differently inclined surfaces of a new technical level horizontal hydraulic classifier with a movable high-speed head of the carrier medium by the flow of solid particles.

Description of the research methodology. The theory of the transfer of single particles of granular material by a two-phase heterogeneous flow in the boundary region between the inclined surface of the classification apparatus and the aqueous medium has been applied. The interaction of a solid particle with an inclined surface under the influence of the high-speed head of an expanding carrier stream, as well as forces of gravity, Archimedes, friction, medium resistance is considered.

Presentation of the main research and explanation of scientific results. Let us consider the process of interaction of a single solid particle with an inclined surface (Fig. 2,a). Let the considered motion of the particle occur along the inclined surface of the expanding flow with its velocity decreasing. The particle undergoes motion under the action of a high-speed head of the pulp, and also forces of gravity, Archimedes, friction, resistance of the medium. We simplify the description of the process by introducing the following assumptions:

a) the soil particles are balls of equal sizes $d_{1}=d_{2}=$ $=d_{n}=\ldots=d_{a d}$. The diameter of particles is taken from the range $d_{a d}=0.16 \ldots 5 \mathrm{~mm}$;

b) the density of the fluid acting on the soil particles, is equal to pseudo-pulp density $\rho_{p}$ with kinematic pseudo-connectivity $v_{p}$.

We give a description of these forces, for the indicated conditions, to the following form: the normal component of the weight of the particle on the bottom surface, $\mathrm{H} F_{g}^{N}=\rho_{s k} \frac{\pi d^{3}}{6} g \cos \alpha_{k}$, where $\rho_{s k}$ is the density of the skeleton of the soil, $\mathrm{kg} / \mathrm{m}^{3} ; d$ is the particle diameter, $\mathrm{m} ; \alpha_{k}$ is the angle of inclination of the bottom classifier surface to the horizontal, deg.:

- tangential component of the force of weight, $\mathrm{H}$ $F_{g}^{\tau}=\rho_{s k} \frac{\pi d^{3}}{6} g \sin \alpha_{k}$;

- the normal component of the Archimedes' force (lifting force) on the bottom surface, $\mathrm{H} F_{a}^{N}=$ $=\rho_{p} \frac{\pi d^{3}}{6} g \cos \alpha_{k}$, where $\rho_{p}$ is the density of the medium (pulp), $\mathrm{kg} / \mathrm{m}^{3}$;

- the tangential component of Archimedes' force, $\mathrm{H}$ (lifting force) $F_{a}^{\tau}=\rho_{p} \frac{\pi d^{3}}{6} g \sin \alpha_{k}$;

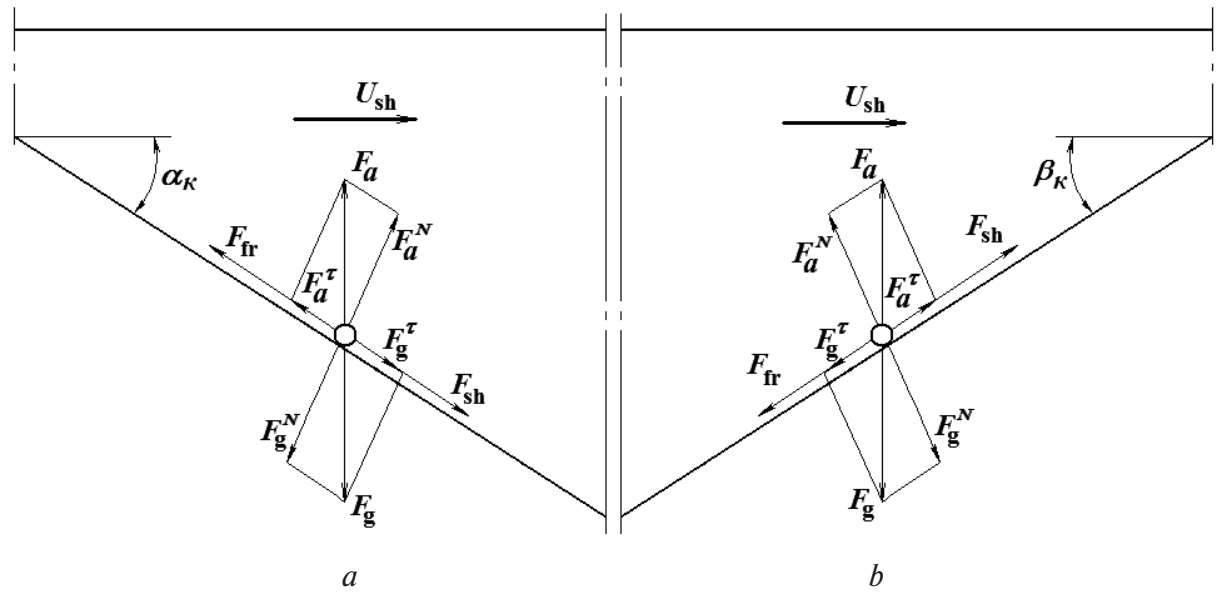

Fig. 2. The calculated scheme of motion of a solid particle along an inclined surface [12]:

$a-$ motion of a particle caused by the pulp velocity pressure as well as by forces of gravity, Archimedes, friction, medium resistance; $b$-upward particle motion 
- the resistance of the medium to the motion of the particle, $\mathrm{H} P=\theta U_{p}^{2} d^{2} \rho_{p}$, where $\theta$ is the coefficient of resistance, $\theta=f(\mathrm{Re}) ; U_{p}$ is the velocity of the particle, $\mathrm{m} / \mathrm{s}$. Let us put the Reynolds number to the form $\operatorname{Re}=\frac{U_{0} d}{v_{p}}$, where $U_{0}$ is the velocity of the carrier medium, $\mathrm{m} / \mathrm{s}$;

- force of high-speed head, $\mathrm{H} F_{\text {sh }}=C_{d} \frac{\pi d^{2}}{4} \rho_{w} \frac{U_{\mathrm{sh}}^{2}}{2}$, where $C_{d}$ is the drag coefficient of the particle;

- the bottom friction force of the particle, $\mathrm{H}$ $F_{f r}=\left(F_{g}^{N}-F_{a}^{N}\right) f_{1}$, where $f_{1}$ is the coefficient of external friction of a considered soil particle on bottom material.

Based on the calculation scheme (Fig. 1), we present the form of recording the friction force to the following form, $\mathrm{H}$

$$
F_{f r}=f_{1} \frac{\pi d^{3}}{6}\left(\rho_{s k}-\rho_{p}\right) g \cos \alpha_{k} .
$$

The general differential equation of the interaction of a single solid particle with an inclined surface, with a downward motion, will take the form

$$
m \frac{d U}{d t}=F_{s h}+F_{g}^{\tau}-F_{f r}-F_{a}^{\tau} .
$$

Experience in the operation of hydraulic classification apparatus indicates low speeds of the carrier medium motion in the gravitational separation of small size solid particles. Therefore, one of the assumptions of the present paper is the absence of a noticeable influence of the medium's resistance forces on solid particles located on the inclined surfaces of the flowing part. Under such conditions, the particle acceleration will be close to zero, that is $m \frac{d U}{d t}=0$. Given the forces acting on the particle, the balance equation of the particle, located on the inclined surface with a downward motion, takes the form

$$
\begin{gathered}
C_{d} \frac{\pi d^{2}}{4} \rho_{w} \frac{U_{s h}^{2}}{2}+\rho_{s k} \frac{\pi d^{3}}{6} g \sin \alpha_{k}- \\
-f_{1} \frac{\pi d^{3}}{6}\left(\rho_{s k}-\rho_{p}\right) g \cos \alpha_{k}-\rho_{p} \frac{\pi d^{3}}{6} g \sin \alpha_{k}=0 .
\end{gathered}
$$

After the transformations, the intermediate notation for the equation of equilibrium has the form

$$
C_{d} \frac{\pi d^{2} U_{s h}^{2} \rho_{w}}{8}=\frac{\pi d^{3}}{6}\left(\rho_{s k}-\rho_{p}\right) g\left(f_{1} \cos \alpha-\sin \alpha_{k}\right) .
$$

Thus, in order to maintain the equilibrium of a solid particle located on an inclined surface, the velocity of the carrier stream (Fig. 2), should be written in the form

$$
U_{s h}=\sqrt{\frac{4}{3} \frac{d g}{C_{d}} \frac{\left(\rho_{s k}-\rho_{p}\right)}{\rho_{p}}\left(f_{1} \cos \alpha_{k}-\sin \alpha_{k}\right)} .
$$

Let us also consider the process of interaction of a solid particle with an inclined surface when moving upwards (Fig. 2, $b$ ). Let the motion of a particle flow along an inclined surface with increasing of the carrier flow velocity. Just as in the calculation scheme (Fig. 2, $a$ ), the particle undergoes motion under the action of a highspeed head of the pulp, as well as forces of gravity, Archimedes, friction, resistance of the medium.

General differential equation for the interaction of a solid particle with an inclined surface without taking into account the forces of the medium resistance has the form

$$
m \frac{d U}{d t}=F_{s h}+F_{a}^{\tau}-F_{f r}-F_{g}^{\tau}
$$

Taking into account the forces acting on the particle, to determine the flow velocity acting on the particle located on an inclined surface (Fig. 2, b), as a result of which it is in equilibrium, we use the formula in the form

$$
U_{s h}=\sqrt{\frac{4}{3} \frac{d g}{C_{d}} \frac{\left(\rho_{s k}-\rho_{p}\right)}{\rho_{p}}\left(f_{1} \cos \beta_{k}+\sin \beta_{k}\right)} .
$$

Let us consider the particular case of a single movement of the soil particle on a horizontal surface (Fig. 3). The particle is affected by the high-velocity head of the pulp, and the forces of gravity, Archimedes, friction, medium resistance.

The general differential equation of a solid particle motion along the horizontal surface of the bottom, without taking into account the forces of medium resistance, takes the form

$$
m \frac{d U}{d t}=F_{s h}-F_{f r} .
$$

Equation of equilibrium of a particle has the form

$$
C_{d} \frac{\pi d^{2}}{4} \rho_{w} \frac{U_{s h}^{2}}{2}-f_{1} \frac{\pi d^{3}}{6}\left(\rho_{s k}-\rho_{p}\right) g=0 .
$$

After the transformations, the equation of the flow velocity acting on a particle located on an inclined surface (Fig. 3), as a result of which it is in an equilibrium state, will take the form

$$
U_{s h}=\sqrt{\frac{4}{3} f_{1} \frac{d g}{C_{d}} \frac{\left(\rho_{s k}-\rho_{p}\right)}{\rho_{p}}} .
$$

It is characteristic that by substituting in formulas 2 , 4 the value of the inclination angle of the bottom surface

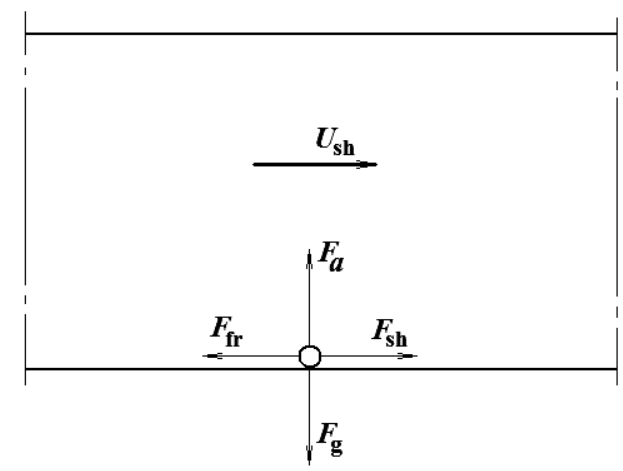

Fig. 3. The calculated scheme of a particle motion along a horizontal surface 
equal to zero, the formula for determining the equilibrium velocity also takes the form of the record 6 .

Let us analyze a more complete picture of the movement of granular material along the inclined surface bottom in the pulp environment. Let us consider the movement of material along the layer of already deposited soil, which is a probable practical case, realized in gravitational concentrators and trays. Schemes of such motion of particles along differently inclined and horizontal surfaces are given in Figs. 4, 5.

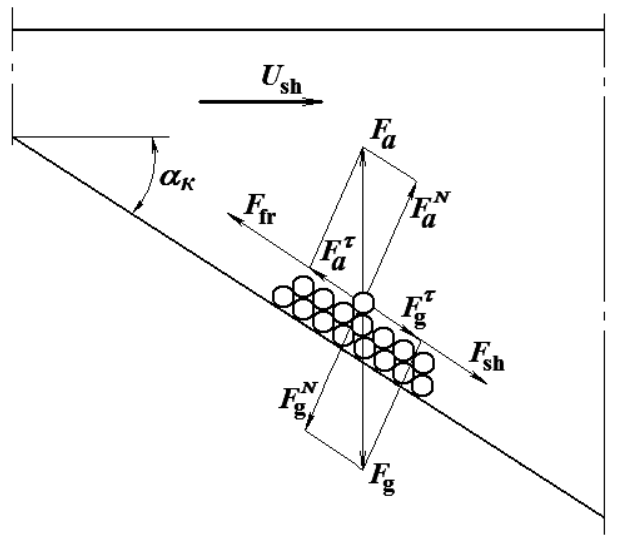

$a$

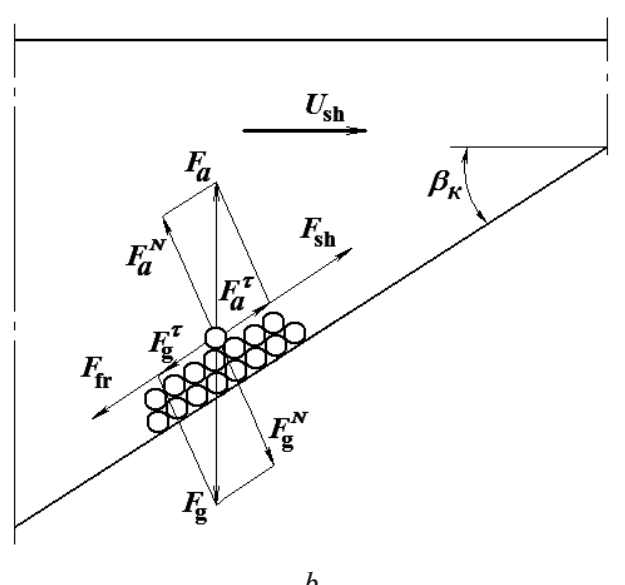

$b$

Fig. 4. Calculation scheme of the motion of a single particle over a layer of granular material deposited on an inclined surface:

$a$-downward movement; $b$ - upward movement

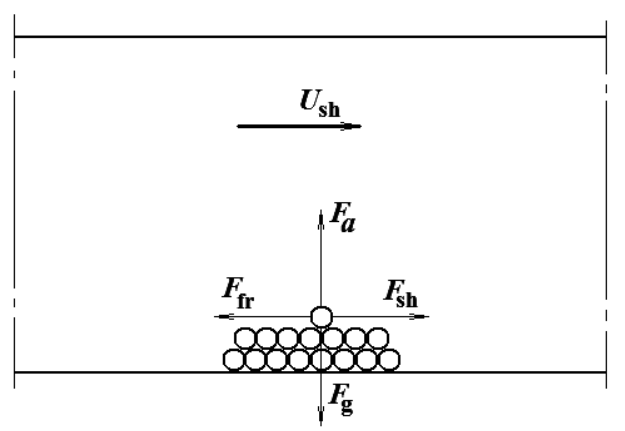

Fig. 5. The calculation scheme of the motion of a particle along a layer of granular material on a horizontal surface
In accordance with the given calculation scheme, the velocity equation of the flow acting on the solid particle, when it is located on a layer of precipitated granular material (Fig. 4), as a result of which the solid particle is in an equilibrium state, has the form:

- for the calculation scheme shown in (Fig. 4,a)

$$
U_{s h}=\sqrt{\frac{4}{3} \frac{d g}{C_{d}} \frac{\left(\rho_{s k}-\rho_{p}\right)}{\rho_{p}}\left(f_{2} \cos \alpha_{k}-\sin \alpha_{k}\right)} ;
$$

- for the calculation scheme shown in (Fig. 4, b)

$$
U_{s h}=\sqrt{\frac{4}{3} \frac{d g}{C_{d}} \frac{\left(\rho_{s k}-\rho_{p}\right)}{\rho_{p}}\left(f_{2} \cos \beta_{k}+\sin \beta_{k}\right)},
$$

where $f_{2}$ is the internal ground friction coefficient.

In the absence of tilt, moving material at the surface occurs in accordance with the calculation scheme (Fig. 5) and the formula 6 for determining the flow velocity, as a result of which the solid particle is in equilibrium, will take the form

$$
U_{s h}=\sqrt{\frac{4}{3} f_{2} \frac{d g}{C_{d}} \frac{\left(\rho_{s k}-\rho_{p}\right)}{\rho_{p}} .}
$$

To determine the numerical values more accurately and to construct a real graphical dependence of the interaction process of solid particles with inclined surfaces, an experimental determination of the external $f_{1}$ and internal $f_{2}$ friction coefficients of the rolled quartz particles was carried out when moving along the basic structural materials of the gravitational devices working surfaces: plexiglass, rubber, steel, polyurethane [12].

As a result of preliminary calculations performed with the use of the dependences obtained earlier to determine the drag coefficient of the particle $C_{d}$ and the experimentally obtained values of the rolled particle friction coefficient, adopted for fine-grained quartz sand on the basis of [13, 14], a graphical dependence of the flow velocity of the medium on the surface inclination angle was obtained (Fig. 6).

In order to justify the parameters of the process of interaction between the inclined bottom of the classifier and solid particles and the development of a model for the movement of granular material along an inclined surface, an experimental determination of the external friction coefficient of the granular material in water was performed. The laboratory installation for determining the external friction coefficient of granular material in water (Fig. 7) consists of a rectangular sealed vessel made of transparent material 1 , an inclined tray 2 with replaceable plates, an adjusting rod 3 with a screw stopper, a protractor 4 , a drain pipe 5 [12]. The inclined tray 2 has the possibility of changing the angle of inclination with respect to the $\mathrm{O}$-axis by means of an adjusting rod 3 with a screw stopper. Measurements of the external friction coefficient of the granular material in water were performed with sand of river natural rolled quartz particles of classes: $2.5 \ldots 5.0,1.0 \ldots 2.5,0.63 \ldots 1.0,0.5 \ldots 0.63$, $0.4 \ldots 0.5,0.315 \ldots 0.4,0.2 \ldots 0.315,-0.2 \mathrm{~mm}$. As a material of interchangeable plates of the inclined tray plexiglass, 


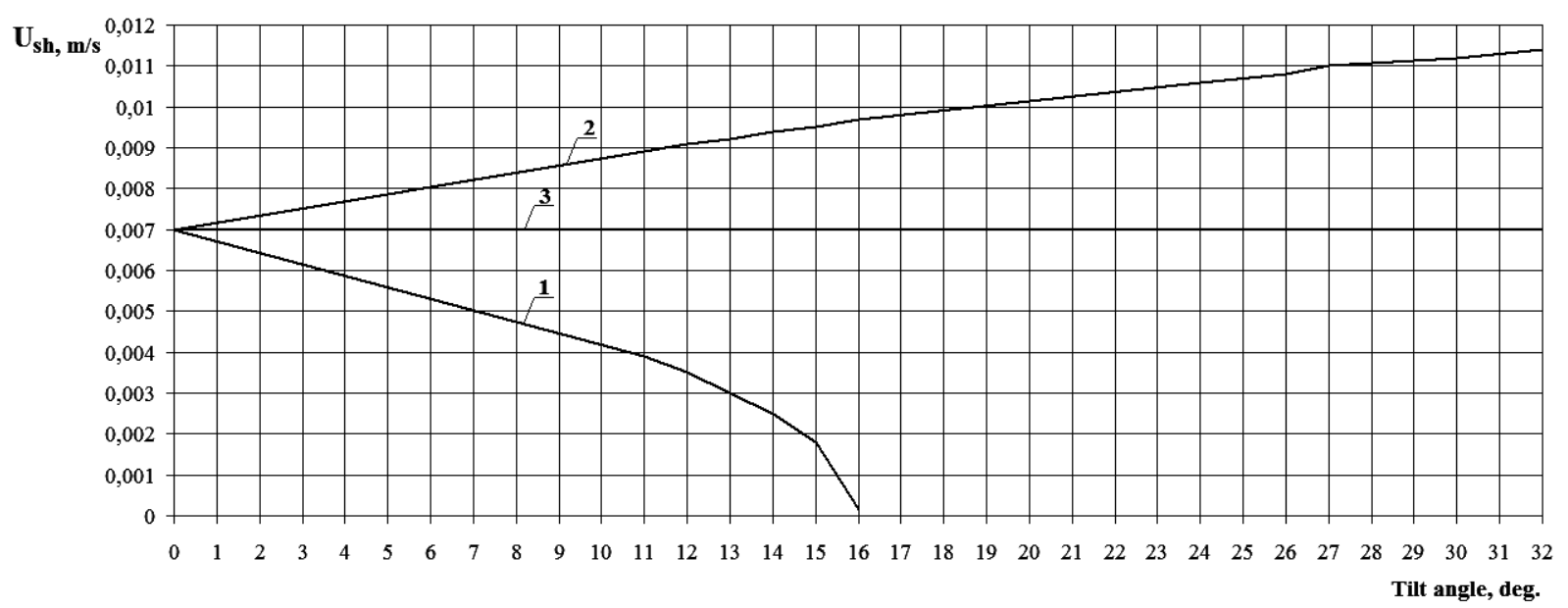

Fig. 6. Dependence of the carrier medium velocity on the inclination angle of the surface at the equilibrium state of the particle:

1 -downward movement; 2 - upward movement; 3 - movement horizontally

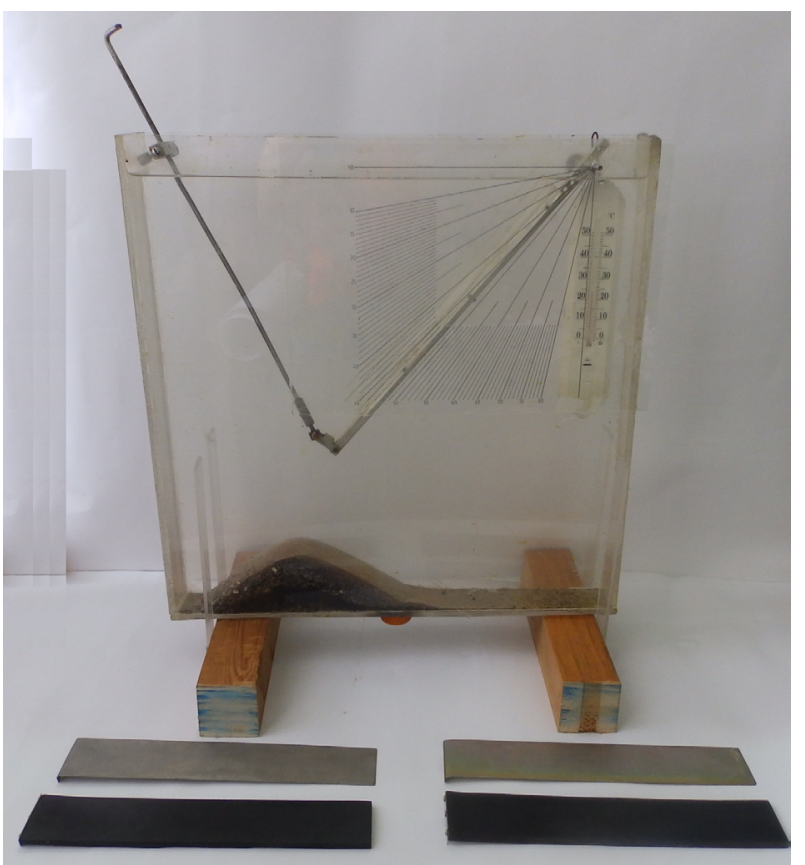

$a$

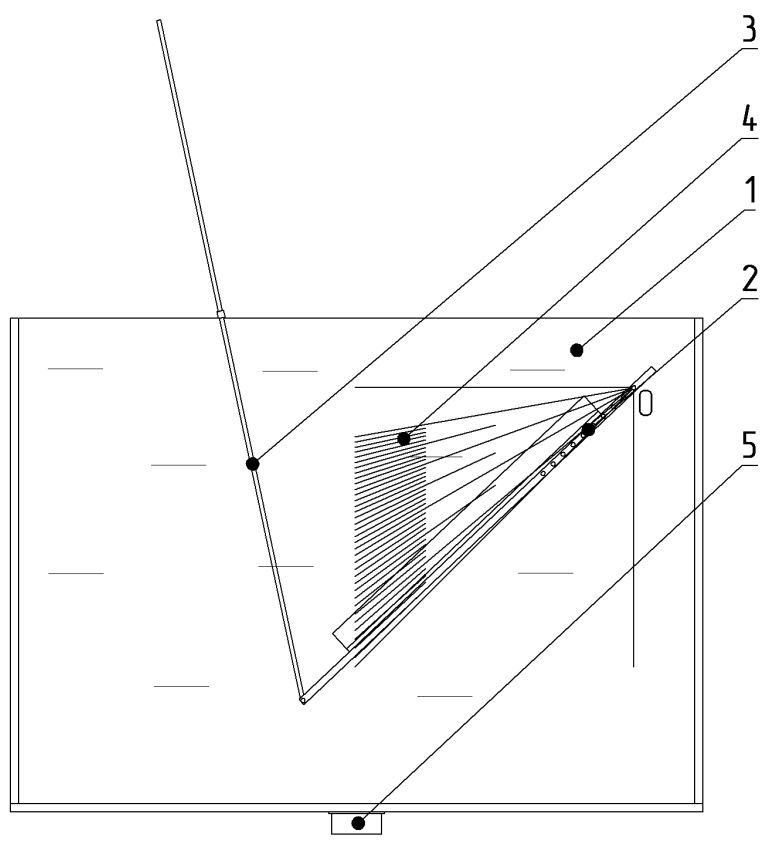

b

Fig. 7. Laboratory installation for determining the friction coefficient of granular material in water:

$a$ - general view of the laboratory installation; $b$ - laboratory installation scheme

rubber, steel, and polyurethane were used. The experimental data obtained at a water temperature of $20^{\circ} \mathrm{C}$ are given in Table [12].

As a result of the experiments, it was established that the value of the external sliding friction coefficient of rolled quartz particles, in water, is greater than on a dry surface. It is also established that the external sliding friction coefficient of quartz particles in water, is a function of the size of the solid particles (Fig. 8). When the particle size of the solid particle decreases, the external sliding friction coefficient increases. Having the experimental values of the external sliding friction coefficient, for rolled quartz particles of different sizes, the graphical form of the dependences 2, 4 characterizing the equilib- rium velocity of a solid particle on an inclined surface under the influence of the velocity head of a carrier fluid flow can be represented as (Fig. 9). The figures show graphical dependencies for the motion of particles on steel. The graphs show that when a solid particle is placed on a downward-inclined surface, in the direction of the carrier stream, characterized by the values of the inclination angle $\alpha_{k} \geq 0$ when $\alpha_{k}$ it changes equilibrium is maintained with a decrease in the flow velocity (Fig. 9, a). A solid particle located on an inclined upstream surface of the bearing surface, at angles $\beta_{k} \geq 0$, requires an increase in the velocity of the carrier flow with an increase in the angle of inclination of the surface $\beta_{k}$ to maintain equilibrium (Fig. 9, b). A solid particle 
Table

Experimental values of the external friction coefficient for river natural rolled quartz sand

\begin{tabular}{|c|c|c|c|}
\hline $\begin{array}{c}\text { Grit size } \\
\text { medium, } d_{a d}, \\
\text { mm }\end{array}$ & $\begin{array}{c}\text { Tray } \\
\text { material }\end{array}$ & $\begin{array}{c}\text { Angle } \\
\text { external } \\
\text { friction, deg. }\end{array}$ & $\begin{array}{l}\text { Coefficient } \\
\text { of external } \\
\text { friction, } f_{1}\end{array}$ \\
\hline 3.75 & \multirow{8}{*}{$\begin{array}{l}\tilde{a} \\
\frac{a}{00} \\
\frac{.00}{x} \\
\frac{0}{2}\end{array}$} & 26 & 0.49 \\
\hline 1.75 & & 27 & 0.51 \\
\hline 0.82 & & 28 & 0.53 \\
\hline 0.57 & & 30 & 0.58 \\
\hline 0.45 & & 33 & 0.65 \\
\hline 0.36 & & 36 & 0.73 \\
\hline 0.26 & & 39 & 0.81 \\
\hline 0.10 & & 44 & 0.97 \\
\hline 3.75 & \multirow{8}{*}{ 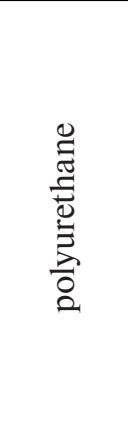 } & 30 & 0.58 \\
\hline 1.75 & & 31 & 0.60 \\
\hline 0.82 & & 32 & 0.62 \\
\hline 0.57 & & 33 & 0.65 \\
\hline 0.45 & & 35 & 0.70 \\
\hline 0.36 & & 38 & 0.78 \\
\hline 0.26 & & 41 & 0.87 \\
\hline 0.10 & & 45 & 1.00 \\
\hline 3.75 & \multirow{8}{*}{$\frac{\bar{\Xi}}{\stackrel{\Xi}{\omega}}$} & 31 & 0.60 \\
\hline 1.75 & & 32 & 0.62 \\
\hline 0.82 & & 33 & 0.65 \\
\hline 0.57 & & 34 & 0.67 \\
\hline 0.45 & & 36 & 0.73 \\
\hline 0.36 & & 40 & 0.84 \\
\hline 0.26 & & 43 & 0.93 \\
\hline 0.10 & & 47 & 1.07 \\
\hline 3.75 & \multirow{8}{*}{$\begin{array}{l}\overline{0} \\
00 \\
0\end{array}$} & 32 & 0.62 \\
\hline 1.75 & & 33 & 0.65 \\
\hline 0.82 & & 34 & 0.67 \\
\hline 0.57 & & 35 & 0.70 \\
\hline 0.45 & & 37 & 0.75 \\
\hline 0.36 & & 41 & 0.87 \\
\hline 0.26 & & 44 & 0.96 \\
\hline 0.10 & & 49 & 1.15 \\
\hline
\end{tabular}

located on a horizontal surface maintains its equilibrium at a constant velocity of the carrier flow not exceeding the critical flushing velocity.

Conclusions and recommendations for further research. In the course of the studies performed, the influence of the function of the surface gradient angle of the classifier on the state of equilibrium of a solid particle washed by a passing flow of a carrier medium is formulated. For this purpose, a mathematical simulation of

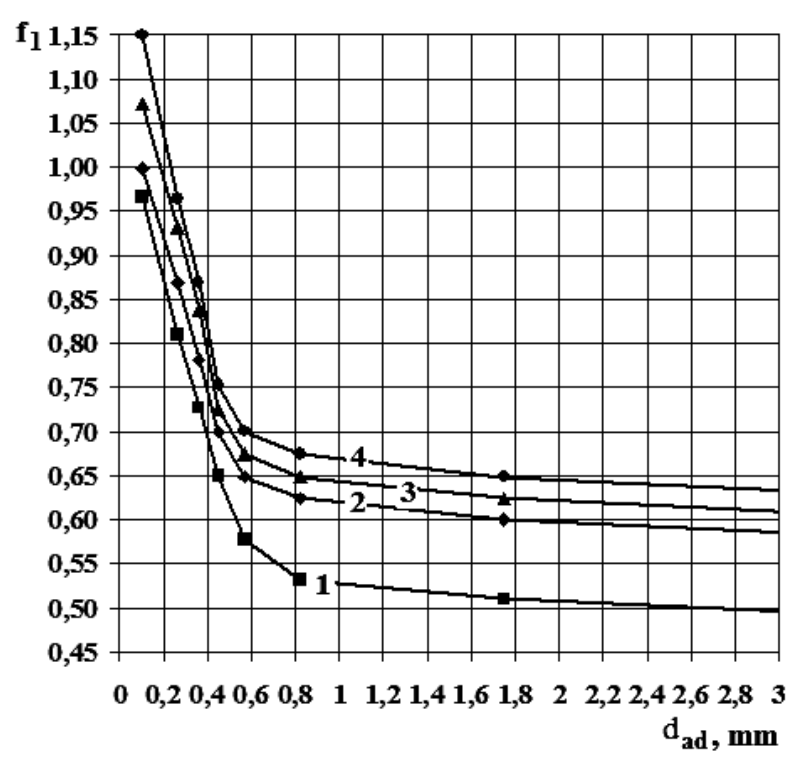

Fig. 8. Dependence of sliding friction coefficient of rolled quartz particles on size:

1 - plexiglass; 2 - polyurethane; 3 - steel; 4 -rubber

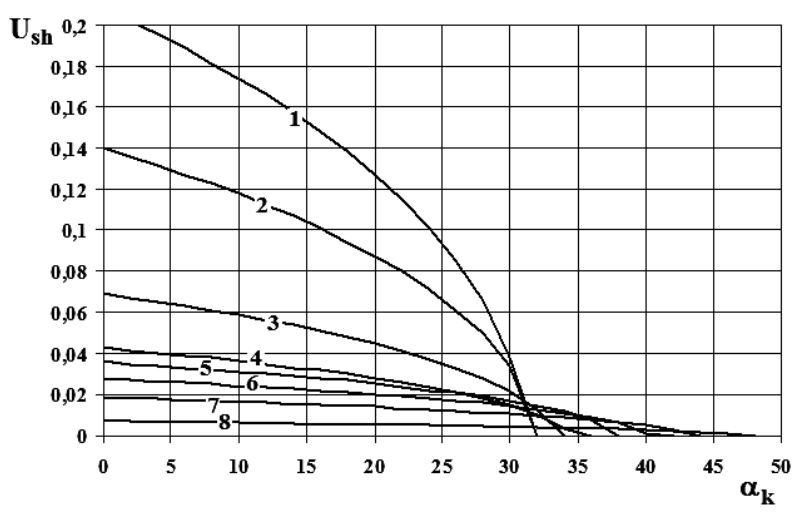

$a$

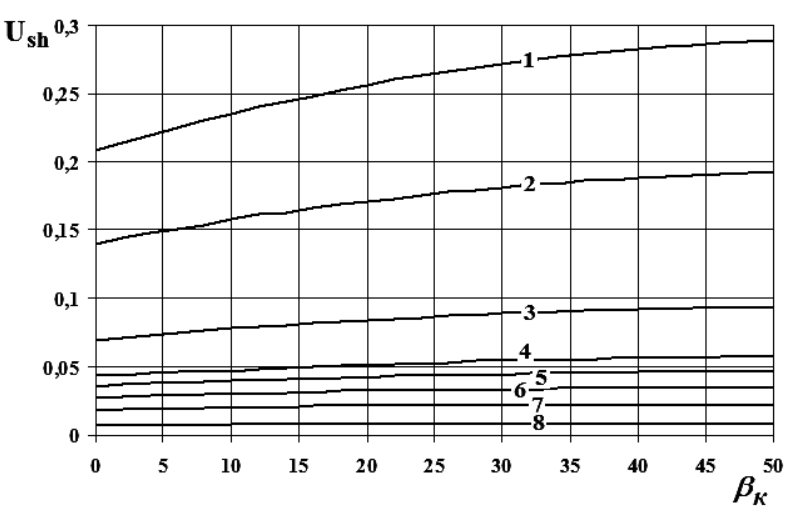

$b$

Fig. 9. The equilibrium field of the rolled quartz particles, the motion along the steel:

$a$ - downward movement; $b$ - upward movement; 1 $2.5 \ldots 5.0 ; 2-1.0 \ldots 2.5 ; 3-0.63 \ldots 1.0 ; 4-0.5 \ldots 0.63$; $5-0.4 \ldots 0.5 ; 6-0.315 \ldots 0.4 ; 7-0.2 \ldots 0.315 ; 8-$ $0.2 \mathrm{~mm}$ 
the interaction of a solid particle driven by a high-speed head of a carrier medium with an inclined surface is performed; analytical dependences were obtained to determine the characteristic velocities of the carrier medium motion required for the equilibrium state of particles deposited on an inclined surface; the form of the graphical dependence of the velocity of the carrier medium on the surface inclination angle at the equilibrium state of the particle is obtained. Parameters are justified and a laboratory facility for determining the external friction coefficient of granular material in water has been developed. The numerical values of the external friction coefficient of granular material in water for rolled river natural quartz sand of narrow size classes are determined.

Project name and number, in which the obtained results are presented. The work relates to the scientific direction of the department of mining machines and engineering SHEE "National Mining University" and performed as part of state budget theme GP-452 (0112U000871) [15] "Development of theoretical foundations for the creation and optimization of modern mining equipment parameters for underwater extraction of minerals".

\section{References.}

1. Smirnov, V.O. and Bilyetsky, V.S., 2012. Pidgotichnyi zbegachennyi korisnichny kopalin. Donetsk: Sci. View. Dim. 2. Smirnov, V.O., Biletsky, V.S. and Sholda, R. O., 2013. Osteoconversion of the corypsis. Donetsk: Sci-dny view. Dim.

3. Gaydin, A. M., Sobko, B. Yu. and Laznikov, O. M., 2016. Mining of flooded deposits of titanium ores. Dnipropetrovs'k : Litograf.

4. Samusya, V., Oksen, Y. and Radiuk, M., 2013. Heat pumps for mine water waste heat. Annual ScientificTechnical Collection - Mining of Mineral Deposits, pp. 153-157.

5. Kolosov, D., Dolgov, O. and Kolosov, A., 2013. The stress-strain state of the belt on a drum under compression by flat plates. Annual Scientific-Technical Collection - Mining of Mineral Deposits, pp. 351-357.

6. Ilin, S.R., Samusia, V.I., Ilina, I.S. and Ilina S.S., 2016. Influence of dynamic processes in mine hoists on safety exploitation of shafts with broken geometry. Naukovyi Visnyk Natsionalnoho Hirnychoho Universytetu, 3, pp. 42-47.

7. Belmas, I. V., Kolosov, D. L., Kolosov, A. L. and Onyshchenko, S. V., 2018. Stress-strain state of rubbercable tractive element of tubular shape. Naukovyi Visnyk Natsionalnoho Hirnychoho Universytetu, 2, pp. 60-69.

8. Bashtovoy, V. G., Rex, A. G. and Chorny, A. D., 2012. Fluid Mechanics. Minsk.: National Technical University. 9. Bondarenko, A.A., 2012. Mathematical modeling of soil dredger absorption processes in the underwater bottomhole. Metallurgical and Mining Industry, 3, pp. 79-81. 10. Bondarenko, A. A., 2012. Laws of determination of fine materials suction limits in submarine suction dredge face. Naukovyi Visnyk Natsionalnoho Hirnychoho Universytetu, 4, pp. 59-64.

11. Bondarenko, A. A., 2018. Theoretical bases of pulp suction process in the shallow dredge underwater face.
Naukovyi Visnyk Natsionalnoho Hirnychoho Universytetu, 3, pp. 22-29.

12. Franchuk, V. P. and Bondarenko, A. A., 2016. Horizontal classifiers. Fundamentals of theory and calculation. Dnipro: National mining university.

13. Nadutyi, V.P., Sukharyov, V. V. and Belyushyn, D. V., 2013. Determination of stress condition of vibrating feeder for ore drawing from the block under impact loads. Metallurgical and Mining Industry, 1(280), pp. $60-62$.

14. Nadutyi, V. P., Sukharyev, V. V. and Beliushin, D. V., 2013. Results of the studies of the impact interaction of lumpy rock mass with lining effective surface of machines. Naukovyi Visnyk Natsionalnoho Hirnychoho Universytetu, 4(136), pp. 54-58.

15. Kyrychenko, V., Samusia, V., Kyrychenko, V. and Goman, O., 2012. Experimental investigation of aeroelastic and hydroelastic instability parameters of a marine pipeline. In: Geomechanical Processes During Underground Mining - Proceedings of the School of Underground Mining, pp. 163-167.

\section{Моделювання взаємодії похилих поверхонь гідравлічного класифікатора $з$ потоком твердих частинок}

\section{А. О. Бондаренко}

Державний вищий навчальний заклад „Національний гірничий університет“, м. Дніпро, Україна, e-mail: Bondarenkoa@nmu.org.ua

Мета. Розробка математичної моделі процесу взаємодії твердої частинки, рухомої швидкісним напором несучого середовища, з похилою поверхнею гідравлічного класифікатора.

Методика. Застосована теорія переносу одиничних частинок зернистого матеріалу двофазним гетерогенним потоком у межовій області між похилою поверхнею класифікаційного апарата й водним середовищем. Розглянута взаємодія твердої частинки з похилою поверхнею під впливом швидкісного напору несучого потоку при його розширенні, а також сил тяжіння, Архімеда, тертя, опору середовища.

Результати. Виконане математичне моделювання процесів взаємодії твердих частинок з похилою поверхнею при впливі швидкісного напору несучого середовища. Розглянуті три характерних режими руху частинки по горизонтальній, нахиленій донизу та нахиленій доверху поверхні. У результаті розробки моделі процесу взаємодії проточної частини класифікатора нового технічного рівня, що сформована різнопохилими поверхнями, з твердими частинками, які омиваються попутним потоком несучого середовища, сформульовані закономірності впливу кута нахилу поверхні проточної частини класифікатора на параметри рівновагового стану твердої частинки. Отримані аналітичні залежності для визначення характерних швидкостей руху потоку несучого середовища, яких достатньо для рівноваги твердої частинки. Установлено, що 
вплив на тверду частинку, розташовану на похилій поверхні класифікатора, несущим потоком, швидкість якого пропорційна куту нахилу поверхні, коефіцієнту тертя-ковзання, характерному діаметру, дозволить їй зберегти свою рівновагу.

Наукова новизна. Отримані аналітичні залежності для визначення характерних швидкостей руху несучого середовища, що необхідні для рівноважного стану частинок, осаджених на похилій поверхні класифікаційного апарата.

Практична значимість. Отримані аналітичні залежності для визначення швидкості потоку середовища, що переносить тверді частинки від кута нахилу стінки проточної частини класифікаційного апарата. Визначені залежності дозволяють виконувати обгрунтування раціональних кутів нахилу поверхонь, які формують проточну частину горизонтальних класифікаторів та інших класифікаційних апаратів, що застосовуються для гравітаційної переробки зернистих матеріалів.

Ключові слова: гідравлічний класифікатор, гравітаційна переробка, похила поверхня, зернистий маmepian

\section{Моделирование взаимодействия наклонных поверхностей гидравлического классификатора с потоком твердых частиц}

\section{А. А. Бондаренко}

Государственное высшее учебное заведение „Национальный горный университет“, г. Днепр, Украина, e-mail: Bondarenkoa@nmu.org.ua

Цель. Разработка математической модели процесса взаимодействия твердой частицы, движимой скоростным напором несущей среды, с наклонной поверхностью гидравлического классификатора.

Методика. Применена теория переноса единичных частиц зернистого материала двухфазным гетерогенным потоком в пограничной области между наклонной поверхностью классификационного аппарата и водной средой. Рассмотрено взаимодействие твердой частицы с наклонной поверхностью под воздействием скоростного напора расширяющегося несущего потока, а также сил тяжести, Архимеда, трения, сопротивления среды.
Результаты. Выполнено математическое моделирование процессов взаимодействия твердых частиц с наклонной поверхностью при влиянии скоростного напора несущей среды. Рассмотрены три характерных режима движения частицы: поверхность горизонтальна, наклонена вниз, наклонена вверх. В результате разработки модели процесса взаимодействия проточной части классификатора нового технического уровня, сформированной разнонаклонными поверхностями, с твердыми частицами, омываемыми попутным потоком несущей среды, сформулированы закономерности влияния угла наклона поверхности проточной части классификатора на параметры равновесного состояния твердой частицы. Получены аналитические зависимости для определения характерных скоростей движения потока несущей среды достаточных для равновесия твердой частицы. Установлено, что воздействие на твердую частицу, расположенную на наклонной поверхности классификатора, несущим потоком, скорость которого пропорциональна углу наклона поверхности, коэффициенту трения-скольжения, характерному диаметру, позволит ей сохранить свое равновесие.

Научная новизна. Получены аналитические зависимости для определения характерных скоростей движения несущей среды, требуемых для равновесного состояния частиц, осажденных на наклонной поверхности классификационного аппарата.

Практическая значимость. Получены аналитические зависимости для определения скорости потока, несущего твердые частицы среды от угла наклона стенки проточной части классификационного аппарата. Установленные зависимости позволяют выполнить обоснование рациональных углов наклона поверхностей, формирующих проточную часть горизонтальных классификаторов и других классификационных аппаратов, применяемых для гравитационной переработки зернистых материалов.

Ключевые слова: гидравлический классификатор, гравитационная переработка, наклонная поверхность, зернистый материал

Рекомендовано до публікаціі докт. техн. наук I.А.Ковалевською. Дата надходження рукопису 05.04.17. 